\author{
International Research Journal of Shariah, \\ Muamalat and Islam (IRJSMI) \\ Journal Website: http://irjsmi.com/ \\ eISSN: 2682-8553
}

\title{
DECISION MAKING BIASES AND ERRORS AMONG MUSLIM GROUPS AND SECTS IN BANGLADESH: A MANAGEMENT PERSPECTIVE
}

\author{
Md. Ariful Islam ${ }^{1}$
}

1 Assistant Professor, Department of Management Information Systems, University of Dhaka, Bangladesh Email: ariful@du.ac.bd

\section{Article Info:}

\section{Article history:}

Received date: 18.03 .2020

Revised date: 14.05 .2020

Accepted date: 28.05 .2020

Published date: 10.06 .2020

\section{To cite this document:}

Islam, M. A. (2020). Decision Making Biases and Errors Among Muslim Groups and Sects in Bangladesh: A Management Perspective. International Research of Shariah, Muamalat and Islam, 2 (4), 55-69.

DOI: $10.35631 /$ IRJSMI.24006.

\begin{abstract}
:
Different Muslim groups/sects in Bangladesh are very intolerant to other groups/sects where Islam teaches brotherhood and unity. This study tried to see the issue from a management perspective, especially in the area of decision making. The study tried to identify the decision-making biases and/or errors among Muslim groups/sects in Bangladesh, and their impacts on their decisionmaking process. The study adopted a model developed by Kieren Jamieson and Paul Hyland (2006). This study followed a qualitative approach. It interviewed 20 Islamic scholars and unity initiators who are working for establishing brotherhood and unity among Muslim groups/sects in Bangladesh. Guidelines have been used while conducting a face-to-face interview. Firstly, the study tried to find whether there are biases and/or errors in the decision-making process among different Muslim groups/sects in Bangladesh, and we found some serious biases and/or errors that can surely lead to biased/inappropriate decisions about other Muslim groups/sects. Secondly, the study tried to specifically find the nature and impacts of those biases and/or errors according to the research framework. It categorized those biases and/or errors in information bias, cognitive bias, risk bias, and uncertainty bias. Those biases and/or errors occurred in the information load, and in the decision-making process. Cognitive biases, the study found, have the most impacts on decision making. From the study, we developed a model to present the decision-making biases and/errors, and their impacts on decisions Muslim groups/sects in Bangladesh take.
\end{abstract}

\section{Keywords:}

Muslim Ummah, Brotherhood, Decision Making Biases And Errors, Unity Of Muslim Ummah, Bangladesh 


\section{Introduction and Literature Review}

Management is to arrange and utilize resources to achieve desired objectives. For that, management goes through planning, organizing, leading, and controlling steps. Management measures its progress and achievement in effectiveness and efficiency. Effectiveness measures whether management is successful or not in attaining the set goals. On the other hand, efficiency measures how much productive the management is in utilizing the resources on the way to getting the goals. (P. Robbins \& A. Coulter, 2018).

In the issue of Muslim Ummah, the objectives of management is to establish brotherhood and unity among different Muslim groups/sects. Muslims are all brothers irrespective of their creed, color, race, sect, ethnicity, language, region, or party. The life, property, and dignity of every Muslim are sacred and protected from any harm by other Muslims. And Muslims are one nation. No division among Muslims are allowed (Naik, 2019). So, the very management measurement applies here is the effectiveness. That is, whether different Muslim groups/sects hold the sense of brotherhood for one another, and whether Muslim groups/sects restrain themselves from posing harm on life, dignity, and property of other Muslim groups/sects. Broadly the unity among different Muslim groups/sects is expected. Unity does not necessarily mean to join a single party or group/sect, rather it is a sense of unity. (Abdullah, 2018) (Akhmetova, 2015) (Ayaz, Ahmad, \& Bhutta, 2018).

The reality of the Ummah today is very pathetic and disappointing. Muslim groups/sects are spreading hatred against other Muslim groups/sects. In many places Muslim groups/sects are fighting directly against other Muslim groups/sects or helping the enemies of Islam to kill or harm other Muslim groups/sects (Muslim Speakers, 2014). The division among Muslim groups and sects is ever increasing. The conflict between Shia-Sunni, Arab-non-Arab, different school of thoughts, political groups, Jihadist groups, Sufi groups, Takfiri groups poisoned the world especially the Muslims world. General Muslims are misguided, confused, and divided. Thus, everyone is being rebuked and most Muslims are rebuking other Muslims. On the other hand, millions of Muslims are being harmed in different forms even displaced, raped, killed, jailed etc. Very unfortunate and sad that Muslims are being happy seeing the misery of other Muslims. Moreover, the Muslim organizations are losing their power and no powerful Muslim organizations are emerging. All these will eventually destroy the Muslim Ummah and make us weak, oppressed, and conflicting groups with no stand in the world. (Farid, 2012).

In Bangladesh the difference between the Salafi and other school of thoughts is ever increasing. The Dewbandi groups are always against the Betlawi and Salafi groups. Betlawi groups strongly rebuke and defame the Salafi groups. Salafis have many groups among themselves. Betlawis have many groups among themselves. Dewbandis have many groups among themselves too. Tablig is a platform motivated and led by the Dewbandi groups and a commonplace for the ordinary Muslims. It has been divided in to two parts recently. Jamate Islami is a moderate Islamic political party with big number of supporters and strong organizational structure. Many people from Salafi, Dewbandi, and Tablig are involved in Jamate Islami. Shia people also live in Bangladesh but very trivial in numbers. There are many Sufi groups working in Bangladesh. Pirs also have a good popularity in Bangladesh especially Charmonai, Sarsina, Furfura, Maijvandari, Atroshi, Dewanbagh, Rajarbagh, Kutubbagh and so on. Lots of Pirs work from their Khanka in local places. Some forbidden and extremist groups also work in Bangladesh. Many deviant groups also active here like Hejbut Tawheed and Ahmadia Muslim Jamat. Overall, the diversity and differences among the Islamic groups are huge in Bangladesh. (Malek, 2015) (Abdullah, 2018) (Naik, 2019). 
Decision making is to choose the best option from alternatives. It is a set of sequential steps through which a formal decision outcome is reached. Decision making is very crucial in management. In every management step, decision making is involved. Appropriateness of decision making has great impacts on the success of management. The very danger to appropriate decision making is the decision-making biases and errors. By 'decision making biases and errors' we mean all the factors misleading to take appropriate decisions, and in this study broadly includes all the information, cognitive, or other biases and errors occurring in the decision-making processes. So, it is very critical to identify and minimize decision making biases and errors for the success of any management. (P. Robbins \& A. Coulter, 2018).

When people make decisions, they not only use their own particular style, they may use "rules of thumb," or heuristics, to simplify their decision making. Rules of thumb can be useful because they help make sense of complex, uncertain, and ambiguous information. Even though people may use rules of thumb, that doesn't mean those rules are reliable because they may lead to errors and biases in processing and evaluating information. (P. Robbins \& A. Coulter, 2018).

Stephen P. Robbins identifies twelve common decision errors and biases that managers make in his great book "Decide \& Conquer" (Robbins, 2004). When decision makers tend to think they know more than they do or hold unrealistically positive views of themselves and their performance, they're exhibiting the overconfidence bias. The immediate gratification bias describes decision makers who tend to want immediate rewards and to avoid immediate costs. For these individuals, decision choices that provide quick payoffs are more appealing than those with payoffs in the future. The anchoring effect describes how decision makers fixate on initial information as a starting point and then, once set, fail to adequately adjust for subsequent information. First impressions, ideas, prices, and estimates carry unwarranted weight relative to information received later. When decision makers selectively organize and interpret events based on their biased perceptions, they're using the selective perception bias. This influences the information they pay attention to, the problems they identify, and the alternatives they develop. Decision makers who seek out information that reaffirms their past choices and discount information that contradicts past judgments exhibit the confirmation bias. These people tend to accept at face value information that confirms their preconceived views and are critical and sceptical of information that challenges these views. The framing bias is when decision makers select and highlight certain aspects of a situation while excluding others. By drawing attention to specific aspects of a situation and highlighting them, while at the same time downplaying or omitting other aspects, they distort what they see and create incorrect reference points. The availability bias happens when decisions makers tend to remember events that are the most recent and vivid in their memory. The result? It distorts their ability to recall events in an objective manner and results in distorted judgments and probability estimates. When decision makers assess the likelihood of an event based on how closely it resembles other events or sets of events, that's the representation bias. Managers exhibiting this bias draw analogies and see identical situations where they don't exist. The randomness bias describes the actions of decision makers who try to create meaning out of random events. They do this because most decision makers have difficulty dealing with chance even though random events happen to everyone and there's nothing that can be done to predict them. The sunk costs error occurs when decision makers forget that current choices can't correct the past. They incorrectly fixate on past expenditures of time, money, or effort in assessing choices rather than on future consequences. Instead of ignoring sunk costs, they can't forget them. Decision makers who are quick to take credit for their successes and to blame failure on outside factors are exhibiting the self-serving bias. Finally, the hindsight bias is the tendency for decision makers to falsely 
believe that they would have accurately predicted the outcome of an event once that outcome is actually known. (P. Robbins \& A. Coulter, 2018).

Decision making biases and errors are not limited to the abovementioned twelve, rather it includes information bias, cognitive bias, risk bias, uncertainty bias, social bias, and so on. Intergroup bias leads people to always support their own group decisions and negating others (Adams, Rehak, Brown, \& Hall, 2009). Because of negativity bias we have a tendency to highlight others' bad issues while not seeing the good sides (Carreti', Mercado, Tapia, \& A. Hinojosa, 2001). Absolute thinking bias is another danger to fair decision making. It takes people in such a position that they treat their thinning absolutely right and never rethink nor listen to others (Al-Mosaiwi, 2018). Many of these biases affect belief formation, business and economic decisions, and human behavior in general. Actually, decision making biases and errors are related to persons and contexts. Managers avoid the negative effects of decision errors and biases by being aware of them and then not using them. Beyond that, managers also should pay attention to "how" they make decisions and try to identify the heuristics they typically use and critically evaluate how appropriate those heuristics are. Finally, managers might want to ask trusted individuals around them to help them identify weaknesses in their decision-making style and try to improve on those weaknesses. (P. Robbins \& A. Coulter, 2018).

Muslim groups/sects have certain dispositions regarding other Muslim groups/sects. Those viewpoints must be reached through a decision-making process. And if there are decision making biases and/or errors in the decision-making process, inappropriate decisions might come. So, it is very necessary to assess whether there are decision making biases and/or errors among the Muslim groups/sects. And from the enmity and disunity among different Muslim groups/sects, it is suspected that there might be some decision-making biases and errors working in their decision-making processes.

As Simon (Simon, Making Management Decisions: the Role of Intuition and Emotion, 1987) noted, intuition does not operate independently of logical analysis as the two elements are complementary in a decision making processes. While Simon understood that elements such as stress play a part in the rationality of decision-making processes, he also noted that there are a number of cognitive and environmental biases that also affect decisions. These biases, in combination with other contextual factors, can radically affect the way information is gathered and processed within the decision-making process. Ultimately, they pose threat to right decisions. (Jamieson \& Hyland, 2006).

There are adequate good researches found on decision making biases and errors in management and psychology discipline, but it is hardly found in the area of Islamic studies, especially in the issue of decision making among Muslim groups/sects. This study hopes to contribute on that very crucial area that might make Muslim groups/sects rethink their decisions and positions about other Muslim groups/sects.

\section{Conceptual Framework}

For this study, we adopted a model developed by Kieren Jamieson and Paul Hyland (Jamieson \& Hyland, 2006) in their paper named "Good Intuition or Fear and Uncertainty: The Effects of Bias on Information Systems Selection Decisions". We adopted the model in our study to identify the decision-making biases and errors among Muslim groups/sects in Bangladesh while dealing one another. As the model is developed for finding the cognitive and other biases, and their effects on decision making, we adopted the model in this study. 
Four groupings of biases that affect decision making are prevalent in the literature. These are information biases, cognitive biases, risk biases, and uncertainty biases. For the purposes of this study, their effects on information and the way information is processed has been developed into a model as depicted in Figure 1. In this model, bias affects decision making in two ways while managers take decisions. Firstly, information flows into a decision-making process and in doing so may pass through one or more bias lenses of filters. A bias lens is a conceptual view through which decision-makers process information. The lens has the potential to screen, alter or intensify the information that enters it. An example of this is an information bias that distorts the perceived benefits of a decision option. Secondly, biases can influence how the decision occurs by shaping the process. An example of this is an uncertainty bias that restricts or stops the search for informing factors. (Jamieson \& Hyland, 2006)

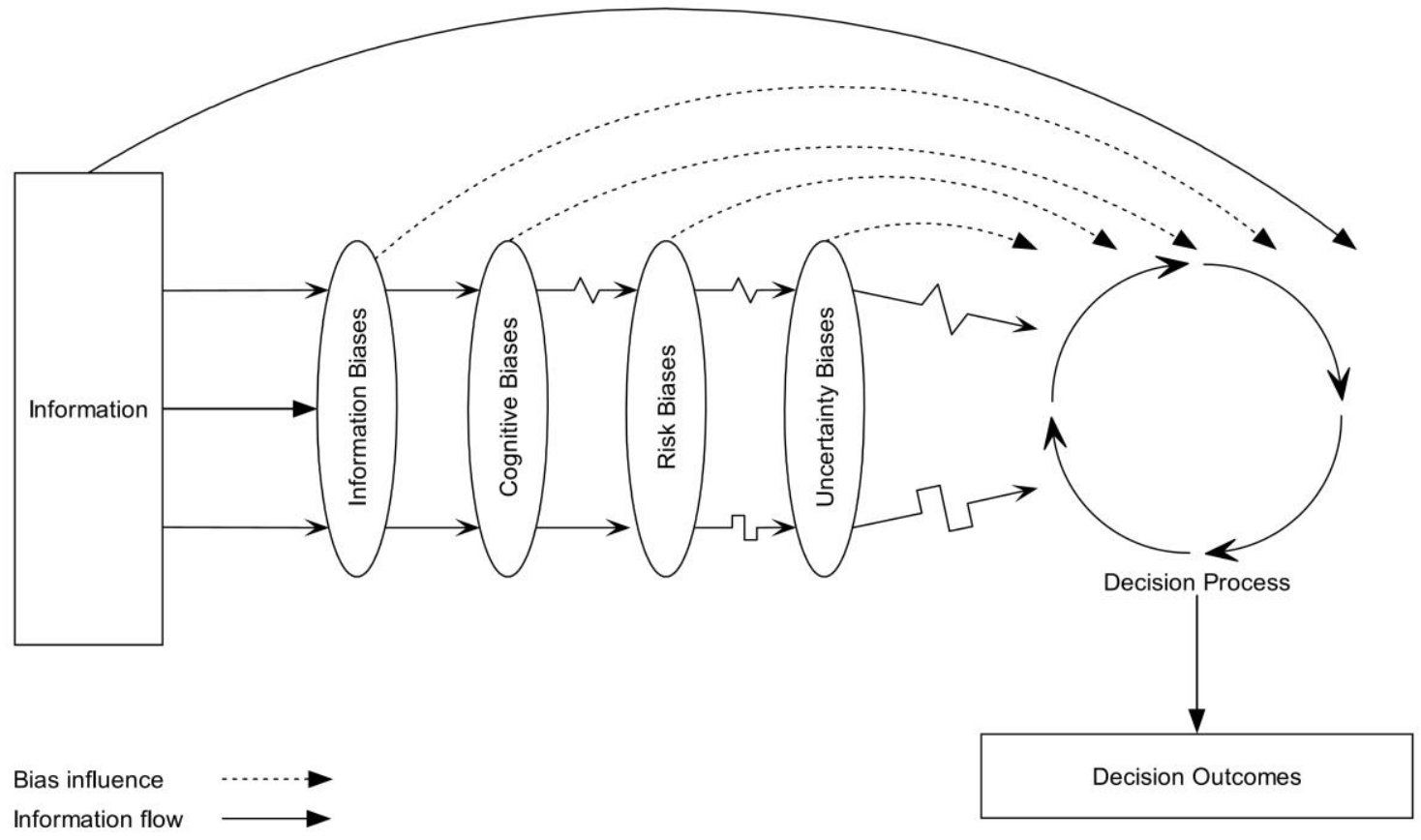

Figure 1 Decision Making Biases \& Errors

Source: (Jamieson \& Hyland, 2006)

Not every bias group is present in all organizations or management decisions. However, from the literature, it is clear they have a role in decision making. In this section, each of the bias groups and their effects are described in order to provide the theoretical background to the research and for later justification of the findings. (Jamieson \& Hyland, 2006)

\section{Information Biases}

Information biases are the first group filters and influences that affect decisions. This is because, when choosing amongst alternatives, decision makers often unconsciously distort information. This is known as desirability bias, optimism, outcome bias, value bias and wishful thinking (Russo, Meloy, \& Medvec, 1998). In their study of pre-decisional information distortion, Russo et al. found that the formation of preferences occurs without instruction and this can lead subsequent pre-decisional distortion of product information. They also found that pre-decisional distortion is proportional to prior confidence in the leading alternative. This means that even when decision makers are not asked to choose an alternative based on information presented to them, they still intuitively form a preference. This preference then 
biases or distorts their decision-making process. Russo et al. also found that even when presented with clear, factual, non-subjective decision relevant diagnostic information that presented contrasting information between alternatives, people still exercised individual predecisional distortion. They note that pre-decisional distortion presents a genuine risk to choose accuracy and provided a reason for this bias. This behavior reinforces the satisficing decision making in Simon's (1967) rational model and his view of administrative behavior and the administrative man (Simon, Administrative behaviour: A study of decision-making processes in administrative organizations, 1997). This means that while information biases can distort information, they can also alter the way in which the search for information occurs. (Jamieson \& Hyland, 2006)

\section{Cognitive Biases}

In order to simplify decision making, a second group of biases, Cognitive biases, are applied to decision making. Duhaime and Schwenk argued that the amount of information available to decision makers often exceeds the decision makers' processing limits (Duhaime \& Schwenk, 1985). Since decision makers are often unable to cope with all the information relevant to a decision, they simplify the decision-making process by applying cognitive filters or biases. Brindle (Brindle, 1999) refers to these biases as cognitive games. The four main biases that Duhaime and Schwenk have identified are reasoning by analogy, illusion of control, escalating commitment and single outcome calculation. Reasoning by analogy is the application of analogies from simple situations to complex strategic problems. Duhaime and Schwenk note that this scaling of analogies from simple to complex problems can lead to an oversimplification of the information to be considered in making the decision. Brindle (Brindle, 1999) calls this bias the misuse of analogy game and described it as the process of comparing and referencing other past decisions to the current decision under consideration. This analogy provokes a subtle emotional bias that causes the decision maker to either focus on or ignore certain information, depending if the information was relevant to the decision that it is being compared to. It will also lead to elimination of decision alternatives if they were similar to failed selected alternatives in previous decisions. Finally, misuse of analogy can be used to build support for a decision alternative. This occurs when an alternative is the same or similar to the alternative in the previous decisions. The illusion of control is where decision makers overestimate the extent to which the outcomes of a decision are under their personal control and their ability to correct or fix problems should they arise as a result of a decision. There is also an overestimation of the personal ability of the decision maker to actually make the decision. This form of bias tends to occur in individuals who have experienced prior success in complex decision making. Decision makers affected by this bias tend to focus on the parts of the decision they can control and not think about the factors that exhibit uncertainty. They also overestimate their own capabilities in order to reassure themselves in the face of uncertainty. Escalating commitment is the tendency for a decision maker to maintain and increase support for a decision, even if the decision appears to be having negative consequences. An example of this occurs when a decision is made to acquire a product. Following the decision, there is a significant feeling of personal responsibility by the decision maker to remain with the product even if it is not performing, thus the bias in this example would deter divestment (Smith \& Keil, 2003). This is a potentially harmful bias as there is evidence of its negative effects, particularly on Information Systems projects, in the paper of Mahaney \& Lederer (Mahaney \& Lederer, 1999). Single outcome calculation is the restriction of decision alternatives to the most promising ones as determined by shared beliefs within the organization at the time of the decision. This provides a rapid convergence of options but restricts creative alternatives. This restriction of alternatives can be as severe as a single option without any search for alternatives. This is common in the case of divestment where the 
organization reaches the collective belief that a failing capital investment decision must be reversed. This type of bias reduces stress in the decision-making process. (Jamieson \& Hyland, 2006).

Other cognitive biases or games include the framing game, the criteria selection game and the rationality game (Brindle, 1999). The framing game is concerned with the way a problem is defined and constrained. If a problem's dimensions are reshaped, this will affect the information sought and decision alternatives. Once framing occurs, there is a commitment to the way in which the decision is being made. This can be thought of as a combination of Bainbridge's (Bainbridge, 2002) overconfidence bias and Duhaime and Schwenk's (Duhaime \& Schwenk, 1985) escalating commitment. Decision makers become attached to their understanding of the problem and the decision alternatives. They become increasingly less predisposed to admit new information and alternatives into the decision making process. Sometimes framing is simply a case of not looking at the real problem (Brindle, 1999). Brindle (1999, p. 609) notes "sometimes, decision makers are not aware of their real agendas, but present the problem, often with perfect integrity, as the way they 'see' it". The criteria selection game is described as the bias decision makers have towards measurable, quantitative data as opposed to less measurable qualitative data (Brindle, 1999). Decision makers like simplified, easy to understand data, even though this may omit details that are necessary in the decision process. Maritan (Maritan, 2001) supports this view with her findings that quantitative data is more heavily relied on for justifying capital investment projects. Visual data, such as graphs and charts, will be more important to decision makers than qualitative arguments (Brindle, 1999). As discussed later, this "game" is the result of uncertainty and the need to reduce information load. Brindle (1999, p. 611) calls the rationality game as "the most insidious game". This bias occurs when decision makers produce rational arguments to constrain the information search or list of alternatives. The underlying reasons for these rational constraints are not examined and are not transparent. These restrictions constrain the decision maker and the ultimate quality of the decision. The key point is that the underlying reasons are not challenged. There is a degree of crossover between this game and Duhaime and Schwenk's (1985) concept of single outcome calculation in that organizational beliefs quickly constrain the alternative list. (Jamieson \& Hyland, 2006).

\section{Risk Biases}

Risk biases form the third group of filters and influences that act on the decision process. These biases mainly act on decision alternatives and minimizing risk during the decision process. The perception of risk can bias decision outcomes because many of the information and cognitive biases that are used by decision makers are also used to mitigate risk. Conventional decisionmaking theory suggests that choice is a combination of risk and expected gain. Decision makers who are risk averse choose alternatives that may have lower potential gains, with smaller variations of outcomes and with relatively low risk. Decision makers who are risk seeking choose alternatives that potentially provide higher gains, though with greater variation in outcomes with higher risks (March \& Shapira, Managerial Perspectives on Risk and Risk Taking, 1987). March and Shapira provide a number of insights into managerial perceptions of risk that showed variations from conventional decision theory. (Jamieson \& Hyland, 2006)

\section{Uncertainty Biases}

The final grouping of biases is Uncertainty biases. These filter and influences act on information and process in order to reduce uncertainty in the decision maker. The level of uncertainty surrounding a decision creates a bias that alters the way in which information is 
gathered and the decision is made. In order to reduce uncertainty, decision maker often use cognitive games, or biases. Uncertainty is the perceived gap between the information available and the information a decision maker wants to have (Buchanan \& Kock, 2000). It is the difference between the knowledge required to make a decision and the knowledge a decision maker has at that time and it is often inversely proportional to the decision-maker's level of understanding of the problem (Falzon, Zhang, \& Davies, 2000). Uncertainty influences both the decision maker and the outcome of the decision and occurs when the decision maker is unable to assign definite probabilities to the consequences of a decision (March \& Simon, Organisations , 1958). In order to reduce uncertainty, decision makers often attempt to acquire more information. Daft and Lengel (Daft \& Lengel, 1984) indicate that as part of this behavior, decision makers often gather and rely on more information from external sources, especially if there are limited internal sources available. However, as discussed later, some research suggests that the acquisition of additional information is not necessarily informing better decisions or reducing uncertainty (Buchanan \& Kock, 2000); (Chan, 2002); (Grisé \& Gallupe, 2000); (Iselin, 1993) and there is considerable evidence to suggest that providing additional information can increase uncertainty levels (Jacoby, 1977). (Jamieson \& Hyland, 2006)

\section{Information}

The measurement of the information used in decision making is described as Information load. Information load is "the variety of stimuli (it consists of all data and information available to the decision maker) to which the receiver must attend" (McCormick, 1970 p. 114) (McCormick, 1970). It consists of external stimuli, dimensions of information, diversity of information and alternatives (Grisé \& Gallupe, 2000). Iselin (Iselin, 1993) separates the concepts of information and data load by defining data load as the number of cues or pieces of data that were not relevant to the decision and information load as the number that were relevant to the decision. This meant that, of the data relevant to the decision, only a given proportion of it could be used as information directly informing the decisions, while the remainder, the data load, was simply discarded. It was found that increasing the data load resulted in poorer decision quality (Iselin, 1993). Part of the problem associated with the way decision makers process information is the way in which data is presented. Decision makers may be more effective when they are presented with data in a form that has a greater cognitive fit with their decision making processes (Mintzberg, 1990); (Umanath \& Vessey, 1994). If data can be manipulated and presented in a more effective way, this may reduce information load, for example, presenting data graphically rather than in tabulated form (Umanath \& Vessey, 1994). There is evidence to suggest that data manipulation leads to more accurate and quicker decisions although more recent studies have suggested that simply converting data into graphs does not necessarily reduce information load (Chan, 2002) (Umanath \& Vessey, 1994). Even so, a cognitive game is played to reduce uncertainty by selecting information that aligns with the decision-making process. (Jamieson \& Hyland, 2006)

\section{Information Overload}

Although uncertainty provokes decision makers to seek more information, increasing information may not decrease uncertainty. As Schroder, Driver and Streufert (Schroder, Driver, $\&$ Streufert, 1967) argue, there is a limit to the amount of information that can be integrated into the decision making process. They maintain that the information absorption peaked, and then declined, as environmental complexity, or the amount of information available to the decision maker, increased. This behavior is described as Information overload and results from "the finite limits of the ability of human beings to assimilate and process information during any given unit of time" (Jacoby, 1977, p. 569). It is a direct result of too much information for the available information processing capacity (Chan, 2002). Information overload has been 
identified as a problem in the management of information systems as it impedes the organization and analysis of ideas and alternatives (Grisé \& Gallupe, 2000). As information load increases, so does the instance of information overload (Grisé \& Gallupe, 2000). This problem has been referred to as "Information Fatigue Syndrome" (Buchanan \& Kock, 2000). If the increase in information creates an information overload, then decision makers have greater uncertainty as they are not only unsure of the decision outcomes, but they are also unsure of which information is most relevant to the decision-making process. (Jamieson \& Hyland, 2006)

The result of this uncertainty is a vicious circle because as information load increases, the proportion of information sought decreases while the number of alternative decision outcomes sought increases (Swain \& Haka, 2000); (Umanath \& Vessey, 1994). This means that as a decision maker is faced with an increasing amount of information relating to a decision, they choose to seek less of it while also searching for more possible decision outcomes or options. This means that the more complex a decision is, the less informed, systematic and thorough the decision-making process will be. This has an adverse effect on decision quality (Chan, 2002)and as Chan (2002, p. 3) notes, "providing more information than they [decision makers] can accommodate will reduce their problem solving effectiveness and lead to poor decisions". The overall effect of the uncertainty biases is one of recursive cognitive games until the decision makers perceive that their levels of uncertainty are lowered to acceptable limits. These games often rely on either selecting data that aligns with their decision making style, or by applying complex uncertainty reduction thought processes similar to the heuristic-systematic decision making style (Eagly \& Chaiken, 1995). The net effect is that the perception of uncertainty can lead to sub-optimal decision outcomes. (Jamieson \& Hyland, 2006)

\section{Objectives}

This study has two objectives. Firstly, to identify, from a management perspective, whether there are decision making biases and/or errors among Muslim groups/sects in Bangladesh regarding one another. Secondly, to find which biases \& errors are there and how they, if any, influence decisions Muslim groups/sects take about other Muslim groups/sects.

\section{Methodology}

This study followed a qualitative approach and based on secondary information. The study compiled the experiences and opinions of the persons who are working for establishing brotherhood and unity among Muslim groups/sects in Bangladesh. The study took opinions and experiences from those people by personal interview. Only those persons are selected for interview who are not advocating or negating any specific Muslim group/sect nor holding positions of any Muslim sectarian organization and working actively for establishing brotherhood and unity of Muslim Ummah in Bangladesh. Convenient sampling has been used for choosing them. National Islamic scholars and unity initiators are selected for the interview. They are selected from different areas of the country but mostly are from Dhaka and Chittagong. In total 15 prominent Bangladeshi Islamic scholars and five unity initiators have been interviewed. Guidelines have been used while conducting the interviews to reach the decision-making issues. Their interviews are then analyzed to identify decision making biases and errors from management perspective according to the conceptual framework. Especially, the nature and occurrence of those biases and/or errors with their respective impacts on different Muslim groups/sects decision making are searched. Those biases and errors with their respective impacts are then grouped in four categories- information bias, cognitive bias, risk bias, and uncertain bias. 


\section{Scope and Limitations}

The study tried to focus only on the issue of decision making and viewpoint of Muslim groups/sects among themselves in Bangladesh. Thus, the study is limited to the area of thinking and decision making of Muslim groups/sects to one another from a management perspective, especially on the ground of decision-making biases and errors. Persons are selected for interview on the basis of convenience, availability, and accessibility. As the data is collected from persons, subjectivity and personal dispositions might be there. For the first objective of this study, hypothesis testing approach would fit better. But actually, it was very difficult for us to follow that approach.

\section{Findings and Discussion}

For the first objective, it is unanimously found that considerable decision-making biases and/or errors occur among Muslim groups/sects while making decisions regarding one other. It is also found that decision making biases and/or errors are mostly not deliberate, rather due to lack of proper methodology and care. Since decision making biases and/or errors are there among Muslim groups/sects, Muslim Ummah fails to attain its objective to establish brotherhood and unity among them. Thus, from management perspective, effectiveness of management is not achieved. Another interesting finding is that, decision making biases and/or errors are not always negative. Sometimes, it brings positive result for the Ummah.

For the second objective, the decision-making biases and/or errors among Muslim groups/sects have been identified and their influence on decision making is also found. We present the findings of the study in four groups according to the model used. The findings are presented here in Table 1.

Table 1: Decision Making Biases and Errors

\begin{tabular}{|c|c|c|}
\hline $\begin{array}{l}\text { Decision Making } \\
\text { Biases and Errors }\end{array}$ & Description of Biases/Errors & Impacts on Decisions \\
\hline Information Bias & $\begin{array}{l}\text { Many Muslim groups/sects have their own } \\
\text { pre-decisional preferences regarding } \\
\text { others. They develop a tendency to attain a } \\
\text { certain desired decision about other certain } \\
\text { Muslim groups/sects. This occur because } \\
\text { of their previous experiences and/or } \\
\text { wishful thinking. For this, they are very } \\
\text { selective in considering information for } \\
\text { their decision making, and not open or } \\
\text { neutral. }\end{array}$ & $\begin{array}{l}\text { This leads to outcome } \\
\text { bias to make biased } \\
\text { decisions. It actually } \\
\text { distorts information as } \\
\text { well as the way to seek } \\
\text { information. It hinders } \\
\text { neutral and fair } \\
\text { assessment of other } \\
\text { Muslim groups/sects. }\end{array}$ \\
\hline Cognitive Bias & $\begin{array}{l}\text { Muslim groups/sects mostly do not go } \\
\text { through a comprehensive assessment of all } \\
\text { information of other Muslim groups/sects. } \\
\text { They try to simplify the decision-making } \\
\text { process by either focusing on or ignoring } \\
\text { certain information. They simply use } \\
\text { comparison and/or referencing from } \\
\text { previous events without analyzing the } \\
\text { current context. Sometimes they } \\
\text { overestimate their ability to analyze } \\
\text { everything regarding other Muslim }\end{array}$ & $\begin{array}{l}\text { This leads to elimination } \\
\text { of all decision } \\
\text { alternatives and focusing } \\
\text { only on the } \\
\text { parts/information they } \\
\text { can control and process } \\
\text { by ignoring others. No } \\
\text { feedback analysis of } \\
\text { previous decisions is } \\
\text { used, rather it blindly } \\
\text { supports them. It also }\end{array}$ \\
\hline
\end{tabular}




\begin{tabular}{|c|c|c|}
\hline & $\begin{array}{l}\text { groups/sects. When Muslim groups/sects } \\
\text { take decisions about other Muslim } \\
\text { groups/sects, they are reluctant to rethink } \\
\text { it, rather they try to increase their support } \\
\text { for that decisions. Sometimes Muslim } \\
\text { groups/sects try to attain single outcome to } \\
\text { reduce decision making stress. They do not } \\
\text { like to deal with multiple decisions } \\
\text { regarding other Muslim groups/sects. } \\
\text { Muslim groups/sects also have a tendency } \\
\text { to use old information regarding other } \\
\text { Muslim groups/sects. They are not much } \\
\text { interested to get the real facts by analyzing } \\
\text { updated information. Muslim groups/sects } \\
\text { are habituated to use measurable and } \\
\text { quantitative information even ignoring } \\
\text { crucial qualitative ones. They try to reduce } \\
\text { uncertainty and information load. Muslim } \\
\text { groups/sects have their own way of } \\
\text { rationalization about other Muslim } \\
\text { groups/sects. Those rationalizations are } \\
\text { often not challenged nor transparent. Most } \\
\text { of them came from their ancestors. }\end{array}$ & $\begin{array}{l}\text { restricts generating or } \\
\text { analyzing all } \\
\text { alternatives. Problem's } \\
\text { dimensions are reshaped } \\
\text { and constrained by the } \\
\text { overconfidence. } \\
\text { Qualitative dimensions } \\
\text { are often not addressed. } \\
\text { Finally, this leads a } \\
\text { certain way of decision- } \\
\text { making process to attain } \\
\text { bias or inappropriate } \\
\text { decisions. }\end{array}$ \\
\hline Risk Bias & $\begin{array}{l}\text { Muslim groups/sects try to minimize risk } \\
\text { of taking different decisions that might } \\
\text { invoke disagreement inside their own } \\
\text { group/sect. They hardly dare to think } \\
\text { beyond their own stereotype way of } \\
\text { decision making. Activists of certain } \\
\text { groups/sects like not to risk their own } \\
\text { position by taking different decisions even } \\
\text { those decisions are more appropriate. It } \\
\text { became a systematic risk because of the } \\
\text { intolerance regarding difference of } \\
\text { opinions among Muslim groups/sects. }\end{array}$ & $\begin{array}{l}\text { This often leads to make } \\
\text { same biases and/or errors } \\
\text { again and again. It } \\
\text { sometimes hinders to } \\
\text { accept better alternatives. } \\
\text { It invisibly creates a } \\
\text { boundary of decision } \\
\text { outcomes. }\end{array}$ \\
\hline Uncertainty Bias & $\begin{array}{l}\text { Muslim groups/sects often use biased } \\
\text { filters to gather information from } \\
\text { information available in the external } \\
\text { sources. When decision makers of Muslim } \\
\text { groups/sects do not have proper knowledge } \\
\text { of the facts, they try to reduce uncertainty } \\
\text { by gathering more information. It is the } \\
\text { difference between the knowledge Muslim } \\
\text { group/sect decision makers require to } \\
\text { make proper decisions and the knowledge } \\
\text { they have. }\end{array}$ & $\begin{array}{l}\text { It influences both } \\
\text { decision makers and } \\
\text { decision outcomes. Only } \\
\text { increasing the } \\
\text { information does not } \\
\text { guarantee to reduce } \\
\text { uncertainly, rather it } \\
\text { often increases } \\
\text { uncertainty leading to } \\
\text { imperfect decisions. }\end{array}$ \\
\hline
\end{tabular}

Source: Author 
Muslim groups/sects suffer from two dimensions of danger in decision making through which biases and errors occur. Firstly, the information load. Information load consists of external stimuli, dimensions of information, diversity of information, and alternatives (Grisé \& Gallupe, 2000). Information load also includes the information sources and the time it is produced or published with proper contexts. It is found that the information load Muslim groups/sects attend is often not proper and lacks contextual facts. Thus, it cannot help taking appropriate decisions regarding other Muslim groups/sects. So, information load needs to be adequate and fair to represent the fact truly.

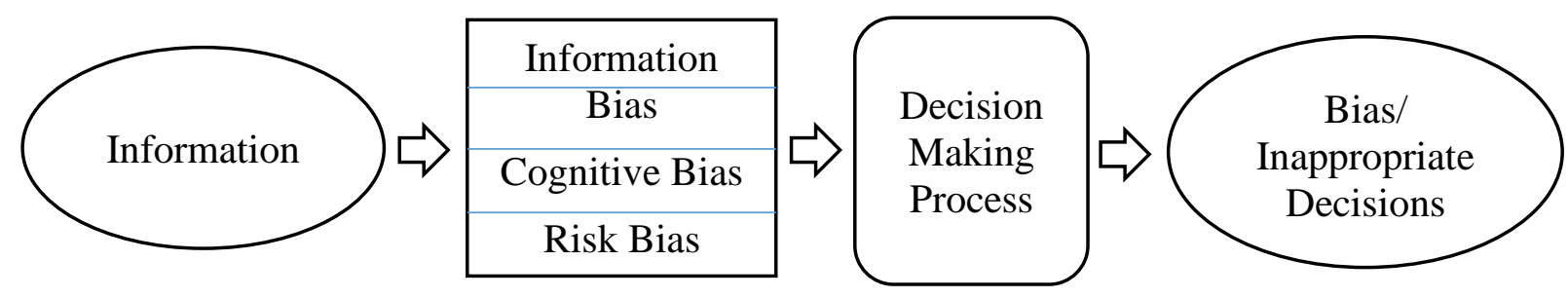

Figure 2: Decision Making Biases \& Errors and their Impacts

Source: Author

Secondly, the decision-making process, the way of processing information. It is also found that Muslim groups/sects have biasness in their own decision-making process to process information, mostly unintentionally and they are actually not aware of those biases. In this stage, the cognitive bias, risk bias, and uncertainty bias happen. More sad issue is that Muslim groups/sects are mostly reluctant to rethink their way of decision making and information processing. They hardly follow comprehensive methodology in decision making regarding other Muslim groups/sects. They often have a self-satisfying tendency and suffer from group bias.

So, the very obvious outcomes of the decisionmaking of different Muslim groups/sects in Bangladesh are prone to be biased or inappropriate. Those biased or inappropriate decisions of Muslim groups/sects can potentially hinder the establishment of brotherhood and unity among Muslims.

\section{Conclusion}

From this study it is clear Muslim groups/sects have biases and errors in their decision-making process. It is not to conclude that those biases and errors are deliberate, and the Muslim groups/sects are happy with them. As the biases and errors are there among Muslim groups/sects, it is of course a subject to rethink. Decision making biases and errors lead to inappropriate decisions and management must be careful about it to minimize them.

Muslim Ummah has the objective to establish brotherhood and unity among different Muslim groups/sects. From that management perspective, Muslim Ummah must address the decisionmaking biases and errors so that Muslim groups/sects became aware of those deadly misleading things. Management literature says that by being aware of the decision-making biases and errors, managers can improve its performance in the scale of effectiveness and efficiency.

Muslim Ummah has many other issues creating obstacles to establish brotherhood and unity among different groups/sects. Using appropriate management model can potentially improve the scenario of the Ummah. 


\section{Further Research}

Based on the findings of this research, another research can be conducted to find the ways to remove or minimize those decision-making biases and errors from Muslim groups/sects in Bangladesh. Furthermore, researches can also be conducted to find all the decision-making issues among Muslim groups/sects.

\section{References}

Abdullah, A. (2018). Unity in Islam. Dhaka: Abdur Rahman.

Adams, B., Rehak, L., Brown, A., \& Hall, C. (2009). Human decision-making biases. Quebec: Defence Research and Development Canada Valcartier.

Akhmetova, E. (2015). Unity of Muslims as a Prerequisite for Successful Islamic Civilisation: Risale-I Nur's Approach. International Conference on Empowering Islamic Civilization in the 21st Century (pp. 78-91). Terengganu: Universiti Sultan Zainal Abidin

Al Al-Alwani, T. J. (2005). Issues in Contemporary Islamic Thought. London: The international Institute of Islamic Thought.

Al-Mosaiwi, M. (2018, May 2). The danger of absolute thinking is absolutely clear Mohammed Al-Mosaiwi | Aeon Ideas. Retrieved June 22, 2019, from Aeon | a world of ideas: https://aeon.co/ideas/the-danger-of-absolute-thinking-is-absolutely-clear

Ayaz, M., Ahmad, H., \& Bhutta, N. (2018). The Foundations of the Unity of Ummah in the Light of Holy Quran and Sunnah. Journal of Islamic Studies and Culture, 6(1), 71-79. doi:10.15640/jisc.v6n1a8

Bainbridge, S. (2002). Why a Board? Group Decisionmaking in Corporate Governance. Vanderbilt Law Review, 55(1), 1-54.

Brewer, M. (1999). Psychology of Prejudice: Ingroup Love or Outgroup Hate? Journal of social psychology, 55(3), 429-444.

Brindle, M. (1999). Games decision makers play. Management Decision, 37(8), 604-612.

Buchanan, J., \& Kock, N. (2000). Information Overload: A Decision Making Perspective. Proceedings of the Fifteenth International Conference on Multiple Criteria Decision Making (MCDM) (pp. 49-58). Ankara: Multiple Criteria Decision Making in the New Millennium.

Carreti', L., Mercado, F., Tapia, M., \& A. Hinojosa, J. (2001). Emotion, attention, and the 'negativity bias', studied through event-related potentials. International Journal of Psychophysiology, 75-85.

Chan, S. (2002). The effect of information load and presentation format on managerial decision quality. Hong Kong: Hong Kong Baptist University.

Creswell, J. (2002). Research Design: Qualitative, Quantitative, and Mixed Methods Approaches. Boston: SAGE Publications, Inc.

Daft, R., \& Lengel, R. (1984). Information richness: A new approach to managerial behavior and organizational design. Research in Organizational Behavior, 6, 191-233.

Dasgupta, N. (2004). Implicit Ingroup Favoritism, Outgroup Favoritism, and Their Behavioral Manifestations. Social Justice Research, 143-169.

Duhaime, I., \& Schwenk, C. (1985). Conjectures on Cognitive Simplification in Acquisition and Divestment Decision Making. The Academy of Management Review, 10(2), 287295.

Eagly, A., \& Chaiken, S. (1995). The psychology of attitudes. Psychology and Marketing, 12, 459-466.

Falzon, L., Zhang, L., \& Davies, M. (2000). A policy analysis approach to operational level course of action analysis. The 5th International Command and Control Technology Symposium. Canberra. 
Farid, A. (2012). Muslim Ummah in the Contemporary world. Dhaka: Islamic Foundation.

Farooqi, A. H. (2000). The division and unity among Muslim Ummah. Dubai: Quran Majlish.

Grisé, M.-L., \& Gallupe, R. (2000). Information Overload: Addressing the Productivity Paradox in Face-to-Face Electronic Meetings. Journal of Management Information Systems, 16(3), 157-185.

Hardman, D., \& Macchi, L. (2003). Thinking: Psychological Perspectives on Reasoning, Judgment and Decision Making. England: John Wiley \& Sons, Ltd.

Hassa, M. (2015). Unity of Muslim Ummah, It's Need, Importance and Suggestions. International Multilingual Journal of Contemporary Research, 3(13), 26-32. doi:10.15640/imjcr.v3n1a3

Hewstone, M., Rubin, M., \& Willis, H. (2002). Intergroup Bias. Annual Reviews Psychology, 575-604.

Iselin, E. (1993). The effects of the information and data properties of financial ratios and statements on managerial decision quality. Journal of Business Finance and Accounting, 20(2), 249-266.

Islam, M. N. (2008). Reasons for disunity among Muslims and ways to solve it. Dhaka: AlUmmah Publications.

Jacoby, J. (1977). Information Load and Decision Quality: Some Contested Issues. Information Load and Decision Quality: Some Contested Issues, 14(4), 569-573.

Jamieson, K., \& Hyland, P. (2006). Good Intuition or Fear and Uncertainty: The Effects of Bias on Information Systems Selection Decisions. Informing Science Journal, 49-69.

Knobloch-Westerwick, S., Mothes, C., \& Polavin, N. (2017). Confirmation Bias, Ingroup Bias, and Negativity Bias in Selective Exposure to Political Information. Communication Research, 1-21.

Kvale, S., \& Brinkmann, S. (2008). Interviews: Learning the Craft of Qualitative Research Interviewing. Boston: Sage Publications.

Mahaney, R., \& Lederer, A. (1999). Runaway information systems projects and escalating commitment. Proceedings of the 1999 ACM SIGCPR conference on Computer personnel research (pp. 291-296). New Orleans: SIGCPR '99.

Majid, K. (2015). Ikhtilaf and Unity in Muslim Ummah: A Comparative Analysis. International Journal of Humanities and Social Science Invention, 3(4), 10-16.

Malek, M. A. (2015). Unity of Muslim Ummah: ways and means. Dhaka: Markazud Dawah Al Islamiah.

March, J., \& Shapira, Z. (1987). Managerial Perspectives on Risk and Risk Taking. Management Science, 33(11), 1404-1418.

March, J., \& Simon, H. (1958). Organisations . New York: John Wiley \& Sons.

Maritan, C. (2001). Capital Investment as Investing in Organizational Capabilities: An Empirically Grounded Process Model. The Academy of Management Journal, 44(3), 513-531.

McCormick, E. (1970). Human Factors Engineering. New York: McGraw-Hill.

Mintzberg, H. (1990). The Manager's Job: Folklore and Fact. Harvard Business Review, 1332.

Molenberghs, P. (2013). The neuroscience of in-group bias. Neuroscience and Biobehavioral Reviews, 1530-1536.

Muslim Speakers. (2014, July 12). How We FAIL as an Ummah - Worth Crying - Mufti Menk You Tube. Retrieved June 21, 2019, from You Tube: https://www.youtube.com/watch?v=DHnE9id9TtA

Naik, D. (2019, June 22). Can the Muslim Ummah Unite Again Under One Nation \& Leadership which was Abolished in 1923?-You Tube. Retrieved June 28, 2019, from You Tube: https://www.youtube.com/watch?v=MgtdxGLvz-U 
One Islam Productions. (2012, May 1). Importance of Muslim Unity \& Jama'ah $\mid$ Khalid Yasin - You Tube. Retrieved June 19, 2019, from You Tube: https://www.youtube.com/watch?v=4s_6JXFu5BY

P. Robbins, S., \& A. Coulter, M. (2018). Management (14 ed.). New Jersey, USA: Pearson Education, Inc.

Qasmi, A., \& Mujtaba, M. (n.d.). Concept of Unity of Ummah and its Sources in the Light of Islamic Teachings. Al Adwa, 46:31, 91-102.

Robbins, S. (2004). Decide \& conquer: make winning decisions and take control of your life (1st ed.). New Jersey, USA: Pearson Education, Inc.

Rozin, P., \& Royzman, E. (2001). Negativity Bias, Negativity Dominance, and Contagion. Personality and Social Psychology Review, 5(5), 296-320.

Russo, J., Meloy, M., \& Medvec, V. (1998). Predecisional Distortion of Product Information. Journal of Marketing Research, 35(4), 438-452.

Schroder, H., Driver, M., \& Streufert, S. (1967). Human information processing: individuals and groups functioning in complex social situations. New York: Holt, Rinehart \& Winston.

Simon, H. (1987). Making Management Decisions: the Role of Intuition and Emotion. The Academy of Management Executive, 57-64.

Simon, H. (1997). Administrative behaviour: A study of decision-making processes in administrative organizations (4th ed.). New York: The Free Press.

Smith, H., \& Keil, M. (2003). The reluctance to report bad news on troubled software projects: a theoretical model. Information Systems Journal, 69-95.

Swain, M., \& Haka, S. (2000). Effects of Information Load on Capital Budgeting Decisions. Behavioral Research in Accounting, 12, 171-199.

Umanath, N., \& Vessey, I. (1994). Multiattribute Data Presentation and Human Judgment: A Cognitive Fit Perspective. Decision Sciences, 25(5-6), 795-823. 